\title{
Fiscal Policy for Growth and Development
}

\author{
Milan Brahmbhatt and Otaviano Canuto
}

The global economic crisis that broke out in 2008 has reawakened interest in fiscal policy. In the early stages of the crisis, there was a widespread turn to countercyclical fiscal stimulus. Furthermore, the recent euro area crisis has underlined the importance of long-term fiscal sustainability for macroeconomic stability. More subtly, the global crisis has also refocused interest in fiscal policy as an instrument for longer-term growth and development. In the potential "new normal" of continued sluggishness in the advanced world, developing countries have strong incentives to seek out new domestic engines for efficiency and productivity growth, as well as for greater equity in development. The potential of fiscal policy to promote these ends is therefore of great interest to developing country policy makers. This note ${ }^{1}$ focuses on that potential and provides an overview of how fiscal positions in developing countries have evolved in the wake of the crisis, as well as some emerging policy lessons. It then sketches a conceptual framework for thinking about the connections between fiscal policy and longer-term growth and development. Finally, this note highlights some findings about the connections between fiscal policy and development.

\section{Context, Recent Trends, and Lessons from the Crisis}

Developing countries entered the recent crisis in a much stronger macroeconomic and financial position than in the past. In general, they had much smaller fiscal and current account deficits, lower inflation, higher international reserves, more flexible exchange rates, lower public and external debt, and less financial sector vulnerability (Canuto and Giugale 2010; Kose and Prasad 2010). ${ }^{2}$ Among middle-income countries, the median ratio of general government debt to gross domestic product (GDP) almost halved, while in a sample of low-income countries (LICs), it fell even more precipitously, aided by substantial debt relief (figure 1).
There was also a swing to greater countercyclicality in the fiscal policy stance of many economies, in contrast to the past, when policy in most countries was procyclical, expanding fiscal stimulus during booms and reducing it during downturns and recessions. Frankel, Vegh, and Vuletin (2011) estimate that the proportion of developing countries pursuing countercyclical fiscal policies increased from less than 10 percent in 1960-99 to over one-third in 2000-2009. ${ }^{3}$ Many were able to increase real government spending in 2009, at the depths of the recession, despite weaker fiscal revenues, in contrast to earlier crises, when countries often had to cut spending, not least on investment projects and social expenditures. Countries that had greater fiscal space before the crisis were able to undertake more significant increases in countercyclical fiscal 
stimulus (Aizenmann and Jinerak 2010; IMF 2010a, 2010b).

How effective were countercyclical programs in developing countries in bolstering short-term growth during the recent crisis? One of the results emerging from recent debates over the effectiveness of countercyclical fiscal policy is that it is likely to be context dependent on the structure of the economy and its overall macroeconomic policy regime. DeLong and Summers (2012) note that what they call the "policy-relevant fiscal multiplier" depends in particular on how monetary policy reacts to fiscal policy shocks. In normal times, monetary policy will be the primary tool for macroeconomic stabilization and will tend to offset fiscal policy shocks, so that estimates of the fiscal multiplier will be quite small. In a depressed economy, however, monetary policy may be much more accommodating of fiscal stimulus, and the policy-relevant fiscal multiplier then would be much larger.

Ilzetzki, Mendoza, and Vegh (2010) estimate that fiscal multipliers in developing countries are generally much smaller than in developed countries, and also document the dependence of multipliers on the structural and macroeconomic context. There is a clear difference between countries with flexible exchange rates, where multipliers are essentially 0 , and those with predetermined exchange rates, where multipliers are over 1 . This gap reflects different monetary policy under the two exchange rate regimes. Under predetermined exchange rates, monetary policy is passive and obliged to accommodate fiscal policy. Under flexible exchange rates, it is autonomous and able to offset fiscal policy shocks. These results are in line with theoretical predictions from standard open economy macro models.

Figure 1. General Government Debt, Medians, 2002-11

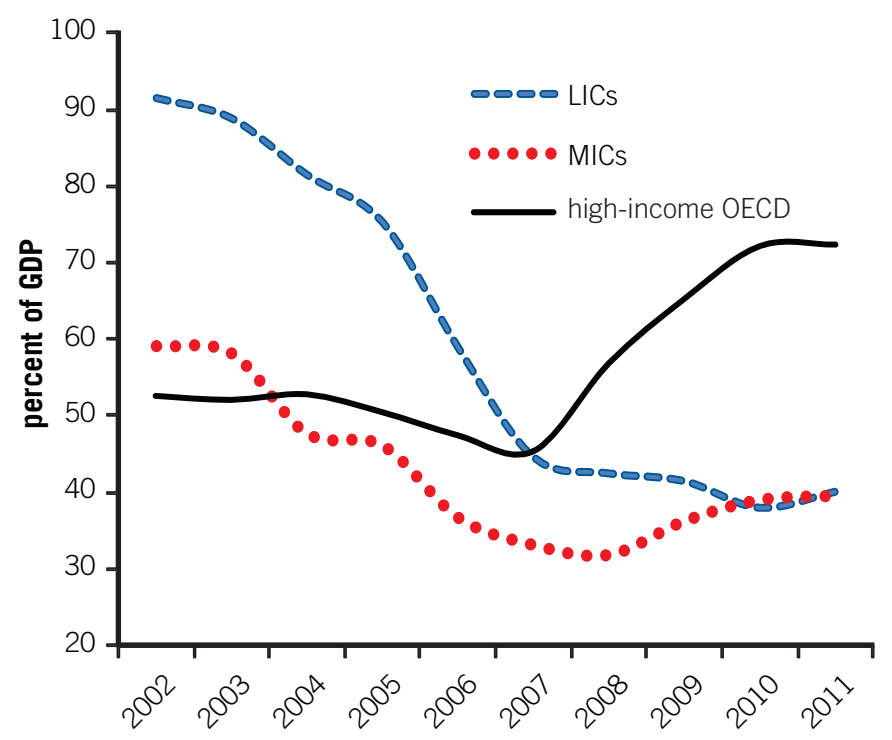

Source: World Economic Outlook Database, International Monetary Fund. Note: $\mathrm{LIC}=$ low-income country; $\mathrm{MIC}=$ middle-income country; $\mathrm{OECD}=$ Organisation for Economic Co-operation and Development.
Fiscal multipliers are also found to be smaller for more open, trade-dependent economies (because of greater import leakage), and even to be negative in the long run for economies with high public debt. Concerns about fiscal sustainability are perhaps less of a constraint on a short-term fiscal stimulus in view of the great fall in public debt-to-GDP ratios in developing countries in the years leading up to the crisis. Nevertheless, median debt ratios have risen by almost 10 percentage points since the start of the crisis in middle-income countries (MICs), and they remain over 55 percent in about one-quarter of developing countries (figure 2).

The case for countercyclical fiscal stimulus will therefore depend on the individual circumstances of each developing country. However, short-term stabilization should not be the only or primary lens through which developing countries assess the usefulness of fiscal policy. Its role in addressing key market failures, improving resource allocation and efficiency, increasing the long-run growth properties of the economy, and addressing issues of distributional equity and social inclusion is likely to have at least as large, if not a greater, influence on social welfare over the long haul.

\section{Fiscal Policy for Growth and Development: A Framework}

A simple framework may help to organize some of these issues. First, what are the development objectives to which fiscal policy should contribute (figure 3)? Growth is clearly one, though policy makers may want to go beyond the standard focus on GDP growth and consider broader measures of in-

Figure 2. General Government Debt, All Developing Countries, 2002-11

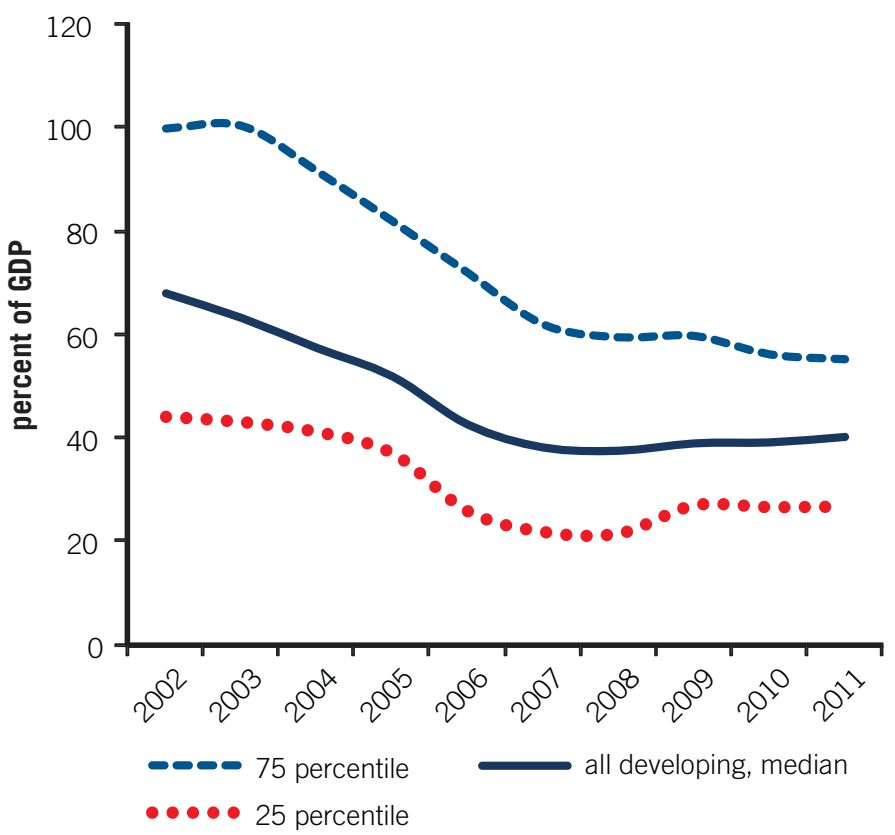

Source: World Economic Outlook Database, International Monetary Fund. 
come, or even expand the focus to growth in a comprehensive measure of wealth. ${ }^{4}$ Poverty reduction, social inclusion, and equity have complex links to growth, but also are rightly viewed as independent development objectives, because the distributional outcomes of market processes may not necessarily jibe with society's normative views on equity. Finally, although sometimes overlooked, there is protection against risk and vulnerability to shocks, which, assuming that most people are risk averse, is also an element of social welfare.

However, one cannot simply assume that there is a role for a government in advancing these development objectives. There must be a clear rationale for public action rather than relying on private markets or on the kinds of self-organizing, voluntary meso-institutions for collective action studied by Ostrom (1990). The traditional threefold rationale for fiscal policy proposed by Musgrave (1959) is still useful: fiscal policy should aim to promote macroeconomic stabilization, improve resource allocation, and address distributional disparities.

The stabilization rationale has both short- and long-run aspects. The short-run aspect focuses on the possibility of using countercyclical fiscal policy to offset the impact of macro- economic shocks that create large or persistent gaps between aggregate demand and potential output, thereby helping to avert both excessive cyclical unemployment and inflationary pressure. From a longer-run perspective, stabilization is also concerned with keeping fiscal deficits and public debt on a sustainable path, so that public finances do not themselves become a source of macroeconomic instability.

As for the resource allocation rationale of fiscal policy, the focus is on the potential for the government to improve economic performance through expenditure and tax policies that boost efficiency (technical and allocative) and improve long-term development performance by dealing with critical market failures. For example, the government might spend on public goods such as law and order, justice, and basic infrastructure, the supply of which also raises productivity and growth in the private sector. Market failures in this context refer not only to the familiar issues of public goods, externalities and increasing scale returns, but also to a variety of information failures and problems of missing markets that can, for example, lead to failures in private insurance markets, creating an efficiency rationale for social insurance policies.

Figure 3. Fiscal Policy for Growth and Development: A Framework

\section{Development objectives}

\begin{tabular}{|c|c|}
\hline $\begin{array}{l}\text { Growth } \\
\text { (wealth, income) }\end{array}$ & $\begin{array}{c}\text { Social risk } \\
\text { management }\end{array}$ \\
\hline \multicolumn{2}{|c|}{ Fiscal policy rationale } \\
\hline \multicolumn{2}{|c|}{$\begin{array}{l}\text { - Macroeconomic stabilization } \\
\text { - Resource allocation: address market failures } \\
\text { - Distribution }\end{array}$} \\
\hline Instruments and institution & Constraints \\
\hline $\begin{array}{l}\text { - Public spending levels, } \\
\text { composition and efficiency } \\
\text { - Tax policies and revenue } \\
\text { mobilization } \\
\text { - Financing and public balance } \\
\text { sheet } \\
\text { - Public financial management } \\
\text { and governance of institutions }\end{array}$ & $\begin{array}{l}\text { - Political economy and } \\
\text { institutional capacity } \\
\text { constraints } \\
\text { - Fiscal sustainability } \\
\text { - Efficiency costs of taxation } \\
\text { and borrowing }\end{array}$ \\
\hline
\end{tabular}


Finally, the distribution rationale underpins fiscal policies that aim to adjust the distribution of income, opportunities, assets, or risk that emerge from private market activity so that it better reflects the ethical views endorsed by society.

There is no simple mapping from rationales to objectives. Fiscal policy undertaken under one or more rationales will typically affect all three development objectives. Thus, for example, a reallocation of public spending toward roads with a net positive effect on growth will also have implications for income distribution and social risk management. If, for example, a new road links a poor remote area to the big city, it could improve the income possibilities for the poor (access to new markets, cheaper farm inputs), as well as their ability to cope with shocks (more diverse job opportunities, urban migration possibilities, and so forth). A road between two wealthy cities might be even better for growth, but worse on the other two counts.

Even when fiscal policy has a clear rationale, key decisions must be made about the appropriate fiscal policy instrument to use, the financing or balance sheet implications of public spending or tax policies, and the institutions that are available to implement such policies in practice, taking into account key constraints and linkages (figure 3). For example, how will changes in the composition of public expenditure or tax structure affect growth and income distribution? The taxes or borrowing needed to finance spending also have their own efficiency costs, and so the benefits of public spending always need to be evaluated net of those costs.

In addition, as noted, fiscal policies need to remain sustainable if they are not themselves to become a source of macroeconomic instability. The government must remain solvent (able to pay off its debts at some future time), liquid (able to meet its current outgoings), and credible (retaining the confidence of investors in its solvency and liquidity). The effectiveness of fiscal programs-for example, the efficiency with which revenues are raised, the cost-effectiveness of public service delivery, or how well public resources are protected from corruption and waste-all depend crucially on the quality of public financial management institutions in a country. Indeed, the costs of government failures may even exceed the costs of the market failures the government is trying to address. Political economy factors and institutional capacity intimately affect a country's ability to actually implement sound fiscal policies.

The sections that follow briefly survey in a little more detail some of the key themes linking fiscal policy and long-run growth and development.

\section{Public Spending and Long-Run Growth}

It is now well understood that specific kinds of public expenditure can make a significant contribution to the level and growth rate of economic output. The government may be able to supply key goods or services that raise the productivity of capital and labor in the private sector, such as infrastructure, research and development (R\&D) or education, but which the private sector itself is unable to provide in optimal quantity or quality because of market failures. And yet relatively little is known about the likely size of the growth effects of various kinds of public spending, particularly in developing countries.

Estimating these effects is not easy because, for one thing, the benefits of a change in public expenditure need to be measured net of the effects of how the expenditure is financed. Most taxes generate distortions and efficiency costs. Public borrowing and growing debt (representing future taxes) can affect growth as well.

The number of empirical studies in developing countries that take proper account of the government's budget constraint is limited. Using an a priori definition of productive spending that includes education, health, housing, transportation, communication, general services, and defense, some of these studies find that more productive expenditures do have a positive impact on growth if they are financed through reductions in other less productive expenditures or through relatively small fiscal deficits, or both. Financing through large deficits appears to be associated with weaker or even negative impacts on growth (Adam and Bevan 2005). Other studies break down government spending between capital and current spending. The effects of capital spending appear to also depend crucially on how it is financed. Several studies find that there is no great growth payoff from boosting capital spending by cutting current spending-indeed, there may be a negative impact. This finding supports the idea that properly selected capital and current spending are complements rather than substitutes-for example, spending on operations and maintenance.

In terms of directions for future research, although government can help overcome market failures, it can also generate institutional failures that reduce incentives and productivity in the private sector. In other words, empirical work in this area will likely be affected by unobserved heterogeneity in governance, institutions, and the overall quality of public spending. ${ }^{5}$

\section{Public Investment Management: Challenges and Tools}

Perhaps the most important variable conditioning the impact of public spending is the quality of public investment management (PIM). A newly developed index of PIM quality shows that only about half of public investment expenditure in developing countries translates into productive capital stocks (Dabla-Norris et al. 2011; Gupta et al. 2011). There is also evidence that public investment spending is higher in countries in which institutional quality is lower because of 
the opportunities for corruption and rent seeking it provides (Keefer and Knack 2007). Poor governance thus leads to more public resources being committed precisely in those circumstances in which the resources are most likely to be squandered on poorly chosen, implemented, and managed public investments.

The institutional challenges of PIM include the assignment of roles and responsibilities for the creation and maintenance of public assets across various agencies and levels of government. Important issues here include how to achieve sufficient coordination between capital and current spending on the operations and maintenance needed to keep assets working effectively, and how to strike a balance between different stages of project selection and management. Budget planning and execution of public investment projects are ideally nested in the context of a medium-term expenditure framework (MTEF), which may help address problems arising from excessive political discretion over projects, myopia, and see-saw or ratchet effects.

New tools that hold promise for helping improve PIM include benchmarking tools such as the IMF's Public Investment Management Index (PIMI) and the World Bank's recently developed Public Expenditure and Financial Accountability (PEFA) diagnostic framework for public capital spending. Greater transparency is a powerful tool for improving public investment performance, particularly when coupled with mechanisms that allow stakeholders-civil society organizations, concerned citizens, the users of public infrastructure, and contractors-to provide decision makers with feedback. The development of information and communications technology can further enhance transparency and social monitoring.

\section{Fiscal Policy for Sustainable Development in Resource-Rich, Low-Income Countries}

Fiscal policy in resource-rich developing countries raises many distinctive issues. Taxation and royalties from natural resources often become the main source of government revenue. International resource prices are highly volatile, tending to induce high volatility in government revenues and economic activity. "Point source" natural resources, such as minerals and oil, become a tempting target for corruption, rent seeking, and even for civil strife and war. Because natural resources are depleting assets, a key question arises about how much to consume today and how much to save for future generations. These problems are exacerbated in LICs, where governance is weak and where present consumption demands by the poor are hard to resist. ${ }^{6}$

Viewed in the context of capital and long-run growth theory, the key to increasing future living standards lies in increasing overall national wealth, which includes not only traditional measures of capital such as produced and human capital, but also natural capital. Standard economic measures of GDP and savings can be inadequate for indicating whether national wealth is indeed rising. Measures of adjusted net national income and savings are needed, which, among other things, take into account the depletion of natural assets as a form of depreciation, complemented by comprehensive measures of the stock of wealth.

To ensure that growth is sustainable in the long-run, resource-rich countries need to capture an efficient and fair share of natural resource rents, and then invest that share effectively to increase the country's wealth. This is where fiscal policy and good public sector governance become essential.

Natural resource funds (NRFs) have long been advocated as an important tool for securing and rationally managing the use of government revenues from natural resources. NRFs are a type of rules-based fiscal policy instrument intended to help overcome political economy problems that favor excessive consumption and plunder of natural resource revenues. Three traditional functions of NRFs are macroeconomic stabilization (to insulate the economy from large fluctuations in resource prices and revenues), stable budget financing (to smooth out the government budget fluctuations), and more optimal savings and investment (to preserve wealth for future generations). However, experience shows that NRFs only work if they change the underlying incentives facing political actors. Here it is helpful to increase transparency and to broaden accountability to include actors outside the executive-for example, the legislature, technical experts, and appropriately qualified civil society organizations.

The government also faces difficult decisions on how much of revenues to pass on to citizens directly through tax cuts or transfers and how much to retain in public hands; on how much of the public share to consume and how much to save and invest; and on how to allocate public investment optimally (for example, between holding foreign assets and engaging in domestic public investments such as infrastructure). A strategy of boosting domestic public investment requires that countries "invest in their capacity to invest"that is, they appropriately appraise, select, and manage public investments so that potential high returns become a reality. A better PIM system increases productivity growth and thus should have a continuing impact on growth, in contrast to reforms that yield a one-off increase in the level of output.

\section{Analyzing the Distributive Effects of Fiscal Policies: How to Prepare (Analytically) for the Next Crisis}

Aggregate cross-country studies typically find that the net impact of the crisis was to slow rather than reverse the ongoing decline in the global poverty rate. Some in-depth microsimulation studies that link macrolevel crisis impacts with detailed household survey data have produced additional interesting 
findings. For example, households made newly poor by the crisis tended to have characteristics different from those of the structural poor; they were more urban, skilled, and less reliant on agricultural income. However, there is relatively little information on the poverty and distributional effects of specific fiscal policy decisions made during the crisis.

There are three main types of analytical tools that could be used to understand the distributional implications of fiscal policies. The first, conventional incidence analysis, is a relatively well-developed set of techniques to estimate how much of a given category of expenditure is received by a particular group in society and how much taxation is borne by each group. The second tool is tax-benefit simulation models. These models allow analysis of the impact of economic shocks or policy changes down to the level of a microdata sample of heterogeneous households. The third type of tool is computable general equilibrium models, which in principle allow a flexible combination of micro- and macrolevel analysis. For example, the MAMS model developed at the World Bank draws on microlevel information about the determinants of outcomes in sectors such as health and education that it uses as input for macro- and sectoral-level analysis of government policies.

There is no single superior technique, but rather there are trade-offs among the simplicity of data needs, analytical assumptions, the readiness to implement, and the comprehensiveness and richness of results to guide policy making. There are additional tools that may help policy makers better prepare to address the distributional impacts of the next crisis. The first is a simple qualitative questionnaire on fiscal decisions implemented at the sectoral level in a given period. The second tool is an approach to conducting ex ante microsimulations that focus on opportunities rather than on outcomes in the hope that the traditional short-term analysis of welfare outputs may be complemented with a discussion of the longer-term effects on equality of opportunity. A case study of Liberia traces the likely impacts of a theoretical cut in educational spending on the probability of access to education for different individuals. This information should be useful in designing more effective policy responses to a crisis.

\section{Fiscal Policy Lessons from the Global Crisis in Africa}

Many African economies saw significant improvements in economic and fiscal performance in the decade before the crisis. Over 70 percent of them were running primary fiscal surpluses (compared with less than 30 percent in the early 1990s); public debt-to-GDP ratios fell sharply, in part because of debt relief, but also because of domestic fiscal adjustment; and many countries were experiencing higher growth and expanding productive public and private investment.
In most African LICs, where automatic fiscal stabilizers are limited, the principal fiscal impact of the crisis was a drop in government revenue. The main fiscal policy instrument available was a discretionary change in expenditure. Governments had a number of fiscal policy options available: adjustment, defined as a cut in spending in response to the revenue drop; accommodation, defined as maintaining spending unchanged; and stimulus, defined as increasing spending notwithstanding the revenue decline. The bulk of countries undertook full or partial accommodation of revenue declines, and some even undertook countercyclical stimulus. Only a small number undertook full adjustment in the face of revenue declines. The more fiscal space a country had built up before the crisis, the less it had to undertake full adjustment and the more options it had to accommodate the revenue shock or even undertake stimulus.

How were countries in sub-Saharan Africa able to finance accommodation or countercyclical stimulus? Official grants and concessional lending remained stable, and African LICs have also traditionally have had limited access to international capital markets, which, in any case, became largely inaccessible during the crisis. However, governments were able to draw on domestic financial markets for the bulk of fiscal stimulus financing. Such markets have grown over the last decade and were able to partly meet the financing challenge without much evidence of crowding out. Going forward, countries in sub-Saharan Africa will need to ensure that the countercyclical increases in government spending undertaken during a crisis do not contribute to a longer-term deterioration in fiscal sustainability.

Many countries wanted to protect public infrastructure programs that had been launched before the crisis with a view to promoting long-term growth. The ability to do this depended crucially on whether they had adequate fiscal reserves from the precrisis boom. In natural resource-dependent countries, this ability was linked to the presence of fiscal rules (such as NRFs) that encourage saving resource-linked revenues during boom times. Where governments had little fiscal space, spending cuts affected more public investment. As for protection of the vulnerable, although well-targeted cash transfers and public works are generally thought to be the most efficient tools in an LIC context, their use in subSaharan Africa has been limited and poorly coordinated. A few governments scaled up spending on such programs where they were already in place. Other governments, however, were tempted to adopt less efficient measures, such as fuel subsidies or producer price supports, for specific export commodities.

However, the actual execution of fiscal plans often lagged. Actual expenditures were often lower than budget, so that the actual fiscal stance was less of a stimulant than intended. The need to improve budget and public investment manage- 
ment is indeed one of the important lessons from the crisis in sub-Saharan Africa. An additional key lesson is the importance of maintaining a prudent, sustainable fiscal stance over the medium term, particularly the need to build up fiscal space during good times to have resources available during a crisis. Experience shows that it is often difficult to reverse discretionary fiscal programs undertaken during a crisis, and so it is important for countries to build safety nets that are effective and affordable in the long run and to ensure that exit strategies from temporary crisis programs are in place.

\section{About the Authors}

Milan Brahmbhatt is Senior Adviser in the World Bank's Poverty Reduction and Economic Management (PREM) Network. Otaviano Canuto is Vice President and Head of the Poverty Reduction and Economic Management (PREM) Network.

\section{Notes}

1. This Economic Premise provides an introduction to the forthcoming volume, Is Fiscal Policy the Answer? A Developing Country Perspective (Moreno-Dodson forthcoming). Subsequent Economic Premises will take up the findings of individual chapters from this volume in more depth.

2. Such a broad assessment is inevitably subject to individual exceptions. For example, several countries in Central and Eastern Europe experienced major private sector credit bubbles financed by foreign borrowing.

3. Frankel, Vegh, and Vuletin (2011) define countercyclicality as a negative correlation between the cyclical components of government expenditure and GDP.

4. On such broader measures of income and wealth, see World Bank (2010).

5. World Bank expenditure tracking surveys, for example, find large variations across countries in the extent to which public spending translates into actual public services or infrastructure.

6. Also see Brahmbhatt and Canuto (2010) for a brief survey of these issues.

\section{References}

Adam, Christopher S., and David L. Bevan. 2005. "Fiscal Deficits and Growth in Developing Countries." Journal of Public Economics 89: 571-97.
Aizenmann, Joshua, and Yothin Jinerak. 2010. "De Facto Fiscal Space and Fiscal Stimulus: Definition and Assessment." Working Paper 16539, National Bureau of Economic Research, Cambridge, MA.

Brahmbhatt, Milan, and Otaviano Canuto. 2010. "Natural Resources and Development Strategy after the Crisis." Economic Premise, No. 1, World Bank.

Canuto, Otaviano, and Marcelo Giugale, eds. 2010. The Day after Tomorrow: A Handbook on the Future of Economic Policy in the Developing World. Washington, DC: World Bank.

Dabla-Norris, Era, Jim Brumby, Annette Kyobe, Zac Mills, and Chris Papageorgiou. 2011 . "Investing in Public Investment: An Index of Public Investment Efficiency.” Working Paper WP/1 1/37, International Monetary Fund, Washington, DC.

DeLong, J. Bradford, and Lawrence H. Summers. 2012. "Fiscal Policy in a Depressed Economy." Paper presented to Spring 2012 Brookings Panel on Economic Activity, March 20.

Frankel, Jeffrey, Carlos Vegh, and Guillermo Vuletin. 201 1. "On Graduation from Procyclicality.” Working Paper 17619, National Bureau of Economic Research, Cambridge, MA.

Gupta, Sanjeev, Alvar Kangur, Chris Papageorgiou, and Abdoul Wane. 2011. "Efficiency-Adjusted Public Capital and Growth." WP/1 1/217, International Monetary Fund, Washington, DC.

Ilzetzki, Ethan, Enrique G. Mendoza, and Carlos A. Vegh. 2010. "How Big (Small) Are Fiscal Multipliers?" Working Paper 16479, National Bureau of Economic Research, Cambridge, MA.

IMF (International Monetary Fund). 2010a. "Emerging from the Global Crisis: Macroeconomic Challenges Facing Low-Income Countries." October 5.

. 2010b. "How Did Emerging Markets Cope in the Crisis?" June 15.

Keefer, Philip, and Stephen Knack. 2007. "Boondoggles, RentSeeking and Political Checks and Balances: Public Investment under Unaccountable Governments." Review of Economics and Statistics 89 (3): 566-72.

Kose, M. Ayhan, and Eswar Prasad. 2010. Emerging Markets: Resilience and Growth amid Global Turmoil. Washington, DC: Brookings Institution Press.

Moreno-Dodson, Blanca, ed. Forthcoming. Is Fiscal Policy the Answer? A Developing Country Perspective. Washington, DC: World Bank.

Musgrave, Richard. 1959. The Theory of Public Finance: A Study in Public Economy. New York: McGraw-Hill.

Ostrom, Elinor. 1990. Governing the Commons: The Evolution of Institutions for Collective Action. Cambridge, UK: Cambridge University Press.

World Bank. 2010. The Changing Wealth of Nations: Measuring Sustainable Development in the New Millennium. Washington, DC: World Bank.

The Economic Premise note series is intended to summarize good practices and key policy findings on topics related to economic policy. They are produced by the Poverty Reduction and Economic Management (PREM) Network Vice-Presidency of the World Bank. The views expressed here are those of the authors and do not necessarily reflect those of the World Bank. The notes are available at: www.worldbank.org/economicpremise. 